\title{
Leading Edge of Plant Protection for Almond
}

\author{
Joseph H. Connell
}

\begin{abstract}
Additional Index words. Prunus dulcis, Prunus amygdalus, pests, diseases, orchard floor management, IPM, integrated pest management

Summary. Almond, [Prunus dulcis (synonym Prunus amygdalus)] planted on approximately $\mathbf{5 9 5 , 0 0 0}$ acres $(240,797 \mathrm{ha})$, is California's largest acreage tree crop. California's Central Valley accounts for nearly $100 \%$ of the U.S. domestic production of almonds. Integrated pest management (IPM) programs that integrate cultural practices and pest and disease monitoring with selective controls have improved plant protection in almond. Methods of orchard floor management and their effects must also be taken into account. Minimizing dust reduces mites while harvesting earlier and the destruction of overwintering refugia are cultural practices that reduce worm damage. Improved methods for field sampling and monitoring have reduced the need for pesticide applications while improving timing and effectiveness of needed crop protection sprays. Selective controls have further reduced the impact on nontarget species. Augmentative parasite releases have also helped manage navel orangeworm (Ameylois transitella). Effective use of new selective fungicides will require precise application timing and greater knowledge of diseases and resistance management. A better understanding of disease life cycles leading to improved monitoring of the fungal diseases, shothole (Wilsonomyces carpophilus), almond scab (Cladosporium carpophilum), and anthracnose (Colletotrichum acutatum) have reduced fungicide applications. Future challenges include the potential loss of effective pest control products, the need to continually develop improved utilization strategies, and maintaining economic sustainability.
\end{abstract}

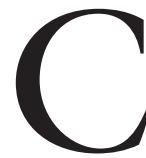
alifornia's central valley produced $77 \%$ of the world's almonds in 2000 on 500,000 bearing acres $(202,350$ ha). An additional 95,000 acres $(38,447$ ha) were non-bearing (California Agricultural Statistics Service, 2001). Spain produced 13\% of the world's almonds followed by Turkey and Greece at 3.8\% each while Italy produced 2.4\%. California acreage is $40 \%$ 'Nonpareil', 17\% 'Carmel', and $10 \%$ 'Butte' while numerous other cultivars constitute the remaining 33\%; $71 \%$ of the California 2000-2001 crop was exported. Almond is California's largest acreage tree crop and almond kernels are the number one United States horticultural export valued at $\$ 586.8$ million (Almond Board of California, 2001).

Almonds are produced primarily in the 400 -mile $(644-\mathrm{km})$ long Central Valley, extending from Tehama County in the north to Kern County in the south. Using up-to-date plant protection techniques in farming requires more knowledge, information, and management skill than in the past. Complex interactions and risks must be considered when making management decisions. Farming cost may be higher for monitoring and unanticipated consequences may require additional treatment intervention if risk assessments do not work out as expected. 
Plant protection practices in almond are developed and introduced by University of California faculty, specialists, and farm advisors working together with innovative growers and production consultants throughout the industry. These practices continually evolve as growers constantly adopt new and more effective practices. Although there is constant change, this paper will highlight examples of progressive techniques in three areas: orchard floor management, insect management, and disease management.

\section{Orchard floor management}

Except in a few areas where large volumes of surface water are available for flood irrigation or where surface sealing slows water penetration, cultivation in California almond orchards is a thing of the past. Non-cultivated orchard floors where middles are mowed and tree rows are kept clean with herbicide strip weed control are today's standard for a variety of reasons. Improved water penetration, better tree nutrition, easier access to the orchard under wet conditions, easier harvest preparation, and less dust with fewer mite problems are just a few of the reasons why non-tillage has been widely adopted (Connell et al., 1996). In a typical almond orchard, middles are mowed, and strips in the tree row are maintained with preemergence, contact, or translocated herbicides.

Some growers avoid herbicides completely by using a propane flamer to keep the strips in the tree row weed free. Flame weed control is designed to kill newly germinated seedlings with heat rather than actually burning weedy materials. Some of these growers also mow half the middle or will mow alternate middles to preserve habitat for beneficial insects. Insectary plant seed mixes are sometimes planted although costs tend to prohibit this practice. A subterranean clover cover crop will fix atmospheric nitrogen but does not fix enough to fully meet almond orchard needs.

Regardless of management choices, a smooth, firm, weed free surface is needed for harvest. This affords better nut drying to preserve quality as well as allowing efficient pickup of the crop. In June, after about five mowings, winter annuals are at the end of their life cycle and summer weeds begin to appear. A translocated herbicide application is made to orchard middles in July to assure that the orchard is weed free for harvest. The required clean harvest condition can be achieved as mentioned or a low rate residual application of oryzalin combined with glyphosate in April or May just before summer weeds germinate can provide season long control. Fewer mowings and only spot weed control treatments are needed when using this approach (Connell et al., 2001).

\section{Insect pest management}

Insect pest management in almonds uses integrated techniques that in many cases allow growers to avoid chemical treatments entirely. Insects are monitored with pheromone traps, sticky traps, and egg traps. Day-degree models define insect life cycles and can identify the potential for crop damage based on the coincidence of pests with susceptible crop stages. Improved control timing allows intervention with selective, short-residual spray materials that are less harmful to beneficial insects. Cultural practices to minimize pest damage are employed, and, releases of beneficial insects may further reduce crop damage (Flint, 2002). Current management techniques for the five most important almond pests, san jose scale, navel orange worm, peach twig borer, ants, and web-spinning mites, are outlined here.

San jose scale (Quadraspidiotus perniciosus) was traditionally controlled with annual dormant applications of oil and organophosphate insecticide. Now a dormant spur sampling can be used to gauge the need for a dormant oil spray and dormant oil alone applied in early to mid-January can provide control of young scales. Male scale flights during the growing season can be easily monitored with pheromone traps. These traps also catch parasites and can be used to judge if they are present in the orchard based on incidental trap catches. Aphytis spp. or Encarsia perniciosiscale parasitoids can be easily distinguished from the male scales in the traps. A day-degree $\left(\mathrm{D}^{\circ}\right)$ phenology model (Rice et al., 1982) can predict crawler emergence (beginning $405 \mathrm{D}^{\circ}$ after the male flight) and can help time a narrow range oil spray to be most effective at 600 to $700 \mathrm{D}^{\circ}$ if the parasitoids need help in controlling the scale. This method can be employed if significant scale populations are noted.
Navel orangeworm (Ameylois transitella) is the major worm pest of almonds. It overwinters in mummy nuts left on the tree after harvest and the first generation in the spring will continue to feed and increase on the remaining mummy nuts. Navel orangeworm infests the new crop once hullsplit begins in July. Winter orchard sanitation to destroy mummy nuts is the most effective control for this pest (Zalom et al., 1984). Removing the mummy nuts from the trees in the winter and chopping them when the orchard floor is mowed in early spring destroys a large percentage of the overwintering worm population and prevents a spring population increase. This cultural control is a much more effective than parasite releases or in-season sprays timed at early hull split.

During the growing season, egg traps baited with ground almond meal moistened with almond oil are used to attract and monitor egg-laying activity and to identify a biofix in the spring (VanSteenwyk et al., 1986). Using egg trap data and the navel orangeworm phenology model, generations can be predicted (Zalom et al., 1998) so that an early harvest can be accomplished in August perhaps before the third generation eggs are laid on the nuts. Traditionally, almond harvest began about 1 Sept. after the nuts were fully split and dry on the tree. Since the navel orangeworm only lays eggs on nuts in the tree, an early harvest when $100 \%$ of nuts are split but not fully dry can help avoid this egg laying, and, crop damage can be greatly reduced (Connell et al., 1989). Early harvest has been widely adopted and when followed by rapid hulling and processing, or, fumigation of stockpiled nuts waiting for hulling, worm damage is minimized.

The parasitic wasp, Goniozus legneri, can help manage the navel orangeworm population most effectively when it is reared and released early in the growing season (Daane et al., 1996). These tiny wasps sting the worm larvae paralyzing it in preparation for egg laying. An egg is laid and the external parasite develops by feeding on the paralyzed larva. At hullsplit, an organophosphate insecticide spray (an old standard control) or Bacillus thuringiensis sprays (Connell et al., 1998) may only be needed if these effective cultural practices and biocon- 
trols have not been thoroughly implemented.

Peach twig borer (Anarsia lineatella), generally feeds in new shoots and can damage new growth on first and second year trees. However, it can also feed on the nuts causing considerable damage. It is effectively controlled with organophosphate dormant sprays aimed at peach twig borer larvae that overwinter in hibernacula in crotches of small twigs. These dormant organophosphate sprays are being phased out since small amounts of pesticide residue have been found in rivers following heavy rains. A widely adopted alternative is the use of Bacillus thuringiensis sprays applied following full bloom and petal fall when the tiny larvae emerge from the hibernacula and feed on the new green growth (Rice et al., 1996). Pheromone traps and a phenology model can help time sprays in May if needed on young trees or in July if the pest population coincides with hullsplit in bearing orchards.

Ants damage almonds primarily by feeding on the kernels while the nuts are drying on the ground during harvest. Ant control must be done earlier in the season before damage is observed. The southern fire ant (Solenopsis xyloni) and the pavement ant (Tetramorium caespitum) are the two damaging ant species that need to be controlled. Other ant species are not harmful or may actually be beneficial such as the gray ant (Formica aerata) which is an excellent peach twig borer predator. Whenever ants are observed, they need to be identified before control measures are implemented (Rice et al., 1996). Field monitoring can be done in June with open vials baited with pieces of hot dog or almond kernels and placed on the ground at intervals throughout the orchard. If significant numbers of damaging ants are detected a selective baiting program can be implemented in the appropriate areas to reduce their numbers before harvest.

Webspinning spider mite management is more effective when a presence/absence sequential sampling scheme is used to help make treatment decisions (Flint, 2002). This scheme involves sampling weekly a minimum of 15 leaves per tree on five trees in mite hot spots and quickly rating each leaf as to whether mites and their predators are present or absent. Counts are compared to a treatment decision chart that helps determine whether or not a treatment is warranted. The webspinning spider mites, pacific spider mite (Tetranychus pacificus) and twospotted spider mite (Tetranychus urticae), can build up quickly to high populations that cause defoliation. Monitoring the population weekly with this sampling scheme prevents surprises and helps determine whether or not a mite treatment is needed. Multiple tactics are used for mite management. These include management to favor mite predators, good irrigation, dust control, and early treatment of mite "hot spots" with low rates of selective acaricides. Management of the beneficial western predatory mite (Galendromus occidentalis) may include supplemental release of these predator mites into the orchard. Orchard wide acaricide application is used only as a last resort.

\section{Disease management}

Disease control has traditionally been based on prevention with fungicides. Brown rot (Monilinia laxa), a disease affecting almond flowers, is a good example of this approach. Control of this disease is simply a matter of applying one fungicide spray at pink bud as a bloom protectant. Available materials are generally very effective on brown rot, and, once treated, the disease is prevented. There are a number of fungicides available for use in almonds that have varying efficacy against the range of almond diseases. New selective fungicides available today often have a shorter residual activity than older fungicides. This requires better knowledge of the target disease and improved application timing. These new fungicides may also have a single site mode of action, which requires that a resistance management strategy be in place. In wet springs when multiple fungicide applications are required, products from different classes must be selected and used in rotation (Teviotdale et al., 2002). Three diseases of almond, shot hole fungus (Wilsonomyces carpophilus), almond scab (Cladosporium carpophilum), and anthracnose (Colletotrichum acutatum) are significant enough that management strategies going beyond fungicide application have been developed.

Shothole fungus outbreaks cause leaf and nut drop and reduce yield. By understanding the disease life cycle and growth parameters this disease can be successfully managed in almond. The disease starts out in the spring from spores that overwinter on the tree. This primary disease cycle is important but generally doesn't result in epidemics. Major disease problems can occur when a secondary disease cycle is completed in the spring with the formation of sporodoccia in shothole lesions on new leaves. The formation of this spore producing structure is influenced by temperature and moisture conditions. The key to effective management is to learn to recognize the formation of sporodoccia in the spring leaf lesions. Their presence followed by rain can lead to epidemic shothole outbreaks. By monitoring for sporodoccia in the spring, fungicide timing does not have to be based solely on potentially disease causing weather conditions. Rather, it can be based on the presence of inoculum in conjunction with additional rainy weather. Thus, fungicide applications may be avoided or their timing can be more effective (Ogawa et al., 1989).

Almond scab produces spots on the hulls and on leaves, which can result in premature defoliation. Once again, recognizing when overwintering twig lesions form spores can indicate when the risk of a disease outbreak has increased. Once spores have formed, additional rain will disperse them and create new infections that can result in undesired defoliation. Recognizing this improves the timing of fungicide applications and the effectiveness of disease control. This understanding helps avoid the epidemic outbreaks that lead to extensive defoliation. If spores have formed but there is no additional threat of rain, additional fungicide application may also be avoided.

The anthracnose fungus causes blossom blight, fruit infections, leaf necrosis, leaf yellowing on entire branches, and branch dieback. As fruit infections progress, the fruit shrivels and the fungus produces a toxin that ultimately kills all tissue beyond the infected fruit. In severe cases with multiple infections, trees experience major branch and limb dieback. This is a new disease to the California almond industry that first resulted in significant damage in the early 1990s. The fungus overwinters in mummified fruit left on the tree and in infected pe- 
duncles. Spores are heavily dependent on splashing water for dispersal and infection. Warm rains from February through June and sprinkler irrigation hitting the foliage from April through July can trigger major outbreaks (Adaskaveg et al., 1998).

Effective management of anthracnose requires a combination of cultural and chemical controls. Sprinkler irrigation should avoid hitting the canopy by using low angle nozzles, and dead wood harboring inoculum must be pruned out. Fungicides effective on this disease are now registered but the best materials are selective short residual, single site mode of action products that must be rotated with other materials for resistance management (Teviotdale et al., 2002). When rain continues in the spring, spray coverage must be thorough and frequent enough to effectively protect the tissues if this disease is to be controlled.

\section{Future challenges}

The leading edge of plant protection in almond requires an integrated approach that combines cultural practices; insect, disease, and weed monitoring; with adequate selective crop protection materials. Two noteworthy challenges include preventing the loss of effective crop protection materials and maintaining the economic sustainability of California almond production.

Due to detection in some California rivers, organophosphates may not always be available. Other materials may accumulate a full risk cup from uses on other crops that could result in loss of registrations on this minor tree crop. The loss of any class of pesticide can potentially cause serious problems because resistance management requires availability of alternative classes of materials. This is especially important for maintaining the effectiveness of new selective fungicides but it can also be important for insecticides since peach twig borer resistance to pyrethroid materials has already been documented (Zalom et al., 2001).
Perhaps the greatest challenge facing the almond producer in California is the economic sustainability of their agribusiness enterprise. Recently, the industry has experienced the lowest prices for almonds in the last 20 years. This is primarily due to heavy production from a steadily increasing acreage. Although almond consumption is growing by over four percent annually, California acreage and production have increased faster in recent years. California producers are proud of the quality and value they provide to the consumer and are hopeful that market demand will catch up with the acreage and production. Using leading edge methods of plant protection helps to maintain the excellent reputation for quality that the California almond industry enjoys.

\section{Literature cited}

Adaskaveg, J.E., H. Forster, R.J. Hartin, J.H. Connell, B. Teviotdale, R. Duncan. 1998. Almond anthracnose in California, A new pre- and postharvest fungal disease outbreak. Acta Hort. 470:553-561.

Almond Board of California. 2001. 2001 Almond almanac. Almond Board Calif., Modesto.

California Agricultural Statistics Service. 2001. Adjusted 2000 California almond acreage survey. Calif. Dept. Food Agr., Sacramento.

Connell, J.H., J.M. Labavitch, G.S. Sibbett, W.O. Reil, W.W. Barnett, and C. Heintz. 1989. Early harvest of almonds to circumvent late infestation by navel orangeworm. J. Amer. Soc. Hort. Sci. 114(4):595-599.

Connell, J.H., W.K. Asai, and H.C. Meith. 1996. Orchard floor management, p.196201. In: W.C. Micke (ed.). Almond production manual. Univ. Calif. Div. Agr. Natural Resources Publ. 3364.

Connell, J.H., F.G. Zalom, and W.J. Bentley. 1998. Navel orangeworm control in almond with Bacillus thuringiensis. Acta Hort. 470:547-552.

Connell, J.H., F. Colbert, W. Krueger, D. Cudney, R. Gast, T. Bettner, and S. Dallman. 2001. Vegetation management options in almond orchards. Hort-Technology 11(2):254-257.
Daane, K.M., G. Yokota, J. Edstrom, R. Jones, W. Bentley, B. Holtz, and J. Brazzle. 1996. Release of Goniozuslegnerifor NOW control, p. 17-19. In: Proc. 24th Almond Ind. Conf., 3-4 Dec. Almond Board Calif., Modesto.

Flint, M.L. (ed.). 2002. Integrated pest management for almonds, $2^{\text {nd }} \mathrm{ed}$. Univ. Calif. Div. Agr. Natural Resources Publ. 3308.

Ogawa, J.M., J.E. Adaskaveg, J.M. Osorio, B.T. Manji, A.I. Feliciano, W.D. Gubler, and B.L. Teviotdale. 1989. Epidemiology and control shot hole, brown rot, leaf rust, scab, and green fruit rot, p. 43-44. In: $17^{\text {th }}$ Annual Almond Res. Conf. Proc., 5 Dec. Almond Board Calif., Modesto.

Rice, R.E., F.G. Zalom, and C. Jorgensen. 1982. Monitoring san jose scale development with degree-days. Univ. Calif. Div. Agr. Natural Resources Lflt. 21312.

Rice, R.E., W.W. Barnett, and R.A. Van Steenwyk. 1996. Insect and mite pests, p. 202-213. In: W.C. Micke (ed.). Almond production manual. Univ. Calif. Div. Agr. Natural Resources Publ. 3364.

Teviotdale, B., J. Adaskaveg, T. Michailides, and D. Gubler. 2002. Fungicide efficacy and timing for deciduous tree fruit and nut tree crops and grapevines 2002. 10 July 2002. <http://www.uckac.edu/plantpath/2002\%20EFFICACY\%20AND\%20TIMING.pdf>.

Van Steenwyk, R.A., W.W. Barnett, W.J. Bentley, J.H. Connell, and D. Rough. 1986. Improved NOW egg traps. Calif. Agr. 40(1-2):24-25.

Zalom, F., C. Weakley, L. Hendricks, W. Bentley, W. Barnett, and J. Connell. 1984. Cultural management of the navel orangeworm by winter sanitation. Calif. Agr. 38(3-4):28.

Zalom, F.G., J.H. Connell, and W.J. Bentley. 1998. Validation of phenology models for predicting development of the navel orangeworm Ameylois transitella (Walker) in California almond orchards. Acta Hort. 470:525-533.

Zalom, F.G., D.B. Walsh, W. Krueger, and J. Connell. 2001. Tolerance of peach twig borer, Anarsia lineatella Zeller, to organophosphate and pyrethroid insecticides (abstr.), p. 83. In: III Intl. Symp. Pistachios and Almond, ISHS, 20-25 May, Zaragoza, Spain. 